\title{
DEVELOPMENT OF FACTORS EFFECTIVE IN THE SUCCESS OF GREEN SUPPLY CHAIN MANAGEMENT
}

\author{
${ }^{1}$ Mahsa Pishdar, ${ }^{2}$ Mohammad Reza Seyyed Hashemi Toloun, \\ ${ }^{3}$ Sima Zamani and ${ }^{4}$ Fereshteh Farzianpour \\ ${ }^{1}$ Department of Production and Operation Management, Allameh Tabatabaii University, Tehran, Iran \\ ${ }^{2}$ Department of Management, Sohrevardi Institution, Qazvin, Iran \\ ${ }^{3}$ Department of Management, Payamnoor University, Tehran, Iran \\ ${ }^{4}$ Department of Health Management and Economics, \\ School of Public Health, Tehran University of Medical Sciences, Tehran, Iran
}

Received 2013-11-26; Revised 2013-12-05; Accepted 2013-12-20

\begin{abstract}
Industrialists and researchers now realize the importance of preserving the environment and principles related to. Sustainable protection can be achieved by protection of environment. Such factors encourage manufacturers to adhere principles of ecological production. In this way, study of factors effective in success of green supply chain management can be really helpful. Assistance to manufacturers having a successful green supply chain is an incentive for this study. Results of this study shed the light on the matter that activities based on green supply chain management approach and external driving factors can affect the efficiency of whole of the supply chain. This means that Industrialists' activities must be in accordance with the principles of environmental protection and they should consider external pressures in order to remain competitive in business world. Besides, results show that environmental regulations, green purchasing and green design are the sub-components that can affect the entire system. However, other sub-components that can have a role in the success of green supply chain management take affection of the whole system instead of influencing it.
\end{abstract}

Keywords: Green Supply Chain, Green Supply Chain Management, External Driving Factors, Organizational Efficiency, Fuzzy DEMATEL Method

\section{INTRODUCTION}

International fluctuating environment and intense competition have brought about the organizations to consider more carefully about the approach for managing their resources and maintain the consequent competitive advantages (Farzianpour et al., 2014). Nowadays, environmental activities play a strategic role in product design planning and working process, senior managers' support for the organization and manufacturing activities and also, influence the organization's manufacturing performance (Tseng, 2011a; 2011b; Tzeng and Opricoric, 2003; Farzianpour et al., 2013a).
Every modern manufacturing organization, for meeting the challenges of a highly competitive world, has to apply the new and innovative strategies, in order to create competitive advantages, meet the stakeholder's needs and consider the legal issues (Farzianpour et al., 2012). Moreover, manufacturing activities are the major factors which have disastrous effects on the balanced ecosystem and might have disruptive influences on the environment in many different periods of product life cycle, such as utilizing the resources, production, supplying the consumers and recycling (Farzianpour et al., 2013b). This represents the importance of manufacturers' caution for manufacturing activities' influences on the Health Management and Economics, School of Public Health, Tehran University of Medical Sciences, Tehran, Iran Tel: +982144648943 
environment. Manufacturers can improve their competitive advantages through complying with the environmental rules and regulations. Recently, considering the environmental regulations has been even much more important than internal activities and has been expanded all over the supply chain. As a result, the supply chain management has been more elaborated in comparison to the past. For managing the supply chain, must give your more attention to the needs of stakeholders and some rules, such as EU's approved rules (EC, 2000; US-AEP, 1999) that appeals manufacturers to take the responsibility for the probable disastrous consequences through the product life cycle. Actually, manufacturing environmentally_friendly products is extremely notable and assists the organizations, with the emphasis on developing green products, in stabling their conditions in the current highly competitive markets (Wallace et al., 2011).

So, This raises the question about the crucial factors which are effective in successful execution of green supply chain plan and also, express the influence of each factor on the whole system, when the entire factors generally create a system. As a result, the purpose of this research is discovering the most crucial effective factors, by studying the research literature and determining their mutual relationships, in order to make the green supply chain much more flourishing (Tseng and Lin, 2009).

We apply the Decision Making Trial and Evaluation Laboratory (DEMATEL) method for answering the research's main question, because it simply divides the effective factors for implementing the green supply chain, with the aid of experts' advice, into two groups; cause and effect (Lin, 2013). Causes are the factors that influence the whole system and their actions can affect the way for obtaining a satisfactory green supply chain. Actually, DEMATEL is a mathematical method that can convert the components of the cause and effect into an illustrative structural model. This method presents the indirect relationships between the system's components in a cause and effect model. Fuzzy sets theory has been used alongside the DEMATEL method for removing any ambiguity in human perception and also, obtaining more thoroughly information.

\subsection{Theoretical Framework}

Global competition has made the relationship between the suppliers and customers more susceptible and the knowledge management has become a key factor in determining the competitive advantages. Nowadays, organizations make more attempts at obtaining the knowledge by improving the efficiency of their supply chain (Li et al., 2011). The occurrence of new requirements among the customers and also the existence of the government's rules and intervention, which affect the bargaining power amongst the supply chain members, arise the necessity of evolving from usual supply chain. For this reason, the green supply management, as a notable philosophy of organization, has been established to meet these needs. Green products and the manufacturing processes that consider these principles, could preserve the environment and make the optimum use of the resources (Diabat and Govindan, 2011; Chung and Wee, 2011). The concept of green supply chain is an interdisciplinary subject which focuses its attention on implementing the environmentally_friendly course of actions in the supply chain. Handling such actions means that the organization to what extent is concerned about the environment and is eager to reduce the harmful effects of its products (Eltayeb et al., 2011).

All people who work for an organization have to realize that with improving collaboration based on the organizational values, they can arouse enthusiasm for raising environmental awareness on the whole supply chain and implement the knowledge management much better (Cheng, 2011). The purpose of the green supply management in not only reducing the expenditure or giving satisfaction to customers_as considered in the usual supply chain_but also paying attention to the environmental issues and the social duty of the organization in this matter. The amount of organization's tendency to make a green supply chain is more affected by the organization's view of the environmental issues (Holt and Ghobadian, 2009). Organizational culture and people's behavior play an important role in converting usual supply chain to the green supply chain (Setthasakko, 2009). If the organization is willing to confirm its position in the environmental issues, must consider its activities and the supporting culture for them, more carefully and select the suppliers who obey the rules (Tseng et al., 2008). The aim of activities related to obtaining the environmental rules in the supply chain, is that to keep a balance between the organization's efficiency in the market and considering environmental matters. Such activities will result in challenges like saving the 
energy and protecting the environment from pollution (Zhu et al., 2011).

Since the businesses manufacture the products designed according to the eco-friendly technology, recycling the products and designing the distribution channels of the supply chain appropriately, they are perfectly capable of reducing the waste, taking advantages of environmental resources and also cutting the economic expenditure. Green activities have positive effect on quality, customer satisfaction and efficiency, that all of the above result in boosting profits (Olugu et al., 2011). Actually, supply chain management involves the integration of different organizations and putting them in the same direction in order to make them indicating the characteristics of the complex systems. Green supply chain management, while it can be implemented well that in the flow of materials and information from suppliers and manufacturers customers there is proper coordination. According to the researchers' findings, there will be more beneficial competitive advantages as a result of existence of harmony through the supply chain (Tseng, 2010).

Because of the importance of this issue, numerous researches have been done in this scope. Some of the relevant researches are as followed: Wang and Zhang (2010) come to a conclusion that with applying DEMATEL method, it will be possible to recognize the direct relationships from the indirect ones in more elaborating issues of supply chain. Also, identify the main factors which can cause the complexity of the system (Wang and Zhang, 2010). Then Lin (2011) realized that under the existing conditions, in which the green supply chain has become a practical approach to the expansion of eco-friendly activities, utilizing the fuzzy DEMATEL method can be useful in evaluating the green supply chain's activities.

According to these researches, we can point out that there are different components involved in succeeding the supply chain. After gathering the components considered in this research, they have been categorized and represent to the experts, in order to get their professional opinions. Major components and the short description of them are included in Table $\mathbf{1 .}$

\subsection{Research Methodologies}

The research, according to its direction and objectives, is a kind of descriptive research. Moreover, it can be considered a survey research, too. Data have been gathered based on the questionnaire measurement tool and sent to the 18 experts of Saipa Automative Manufacturing Group, in order to get their professional opinion. The reason for choosing such a manufacturing group is that, this group considers the green supply and endeavors to follow the rules of safeguarding the environment to such an extent that the Saipa Yadak_a spare parts supplier and one of the members of Saipa Group_won a prize in the third festival of green economy. Selected experts are really experienced and well-informed about the managerial knowledge and concepts used in questionnaire.

For determining the mutual effects of the components used in the green supply chain management, DEMATEL method has been applied. This method with the aid of structural modeling approach, divide the components into two separate categories; cause and effect. This helps the researchers to gain a better understanding of the structural relationships between the factors (Lin, 2011; Wang and Zhang, 2010).

The vast majority of organizations for dealing with the decision making issues, faced with in the real world, apply the group decision making methods. But while we are confronting the complicated systems, the experts' opinion becomes more explanatory and gives up its absolute values. This sort of opinions make the decision making process much more complicated and causes the ambiguity (Tzeng and Opricovic, 2003). Therefore, the fuzzy theory developed by Dr. Asgarzadeh in order to take advantages of ambiguous data in analyzing the matters (Zadeh, 1965). In this research, the Triangular Fuzzy Numbers (TFN) have been used, because they can be calculated more easily and have a surprising degree of accuracy. A sample of the triangular fuzzy numbers showed in the Fig. 1, as (a1, a $\mu, a 2)$.

The membership function of the triangular fuzzy numbers defined as followed:

$$
\mathrm{A} \Delta \mu_{\mathrm{A}}(\mathrm{x})=\left\{\begin{array}{c}
\frac{\mathrm{x}-\mathrm{a}_{1}}{\mathrm{a}_{\mu}-\mathrm{a}_{1}} \mathrm{a}_{1} \ll \mathrm{x} \ll \mathrm{a}_{\mu} \\
\frac{\mathrm{x}-\mathrm{a}_{2}}{\mathrm{a}_{\mu}-\mathrm{a}_{2}} \mathrm{a}_{\mu} \ll \mathrm{x} \ll \mathrm{a}_{2} \\
0
\end{array}\right\}
$$


Table 1. Components of the research

\begin{tabular}{|c|c|c|c|}
\hline \multirow{2}{*}{\multicolumn{4}{|c|}{$\begin{array}{l}\text { Code Component } \quad \text { Short Description } \\
\text { Green supply chain management activities }\end{array}$}} \\
\hline & & & \\
\hline $\mathrm{C} 1$ & Green purchase & $\begin{array}{l}\text { All the activities that ensure the manufacturing } \\
\text { items are bought based on the environmental principles. } \\
\text { Raw materials that can be used for making products are } \\
\text { recyclable and they do not harm the environment. }\end{array}$ & $\begin{array}{l}\text { (Igarashi et al., 2013; Hervani et al., } \\
\text { 2005; Wheeler et al., 2013; } \\
\text { Zhu et al., 2007) }\end{array}$ \\
\hline $\mathrm{C} 2$ & Green designing & $\begin{array}{l}\text { Designing the product with the intention of decreasing } \\
\text { the harmful impact of the products on the environment } \\
\text { during the product life cycle. }\end{array}$ & $\begin{array}{l}\text { (Kanan et al., 2014; Hervani et al., } \\
\text { 2005; Zhu et al., 2007) }\end{array}$ \\
\hline $\mathrm{C} 3$ & Reverse logistics & $\begin{array}{l}\text { All the activities done with the purpose of } \\
\text { recycling and reusing the products. }\end{array}$ & $\begin{array}{l}\text { (Alvarez-Gil et al., 2007; Kanan et al., } \\
\text { 2014; Richey et al., 2005) }\end{array}$ \\
\hline $\mathrm{C} 4$ & $\begin{array}{l}\text { Close cooperation } \\
\text { with customers }\end{array}$ & $\begin{array}{l}\text { All the activities done with the purpose of improving } \\
\text { the eco-friendly performances enhance the customers' } \\
\text { abilities in order to encourage them to take part in } \\
\text { different projects, develop the green products and } \\
\text { indicate the efficient innovations in this scope. }\end{array}$ & $\begin{array}{l}\text { (Chan et al., 2012; } \\
\text { Vachon and Klassen, 2006; 2007) }\end{array}$ \\
\hline C5 & $\begin{array}{l}\text { Close cooperation } \\
\text { with suppliers }\end{array}$ & $\begin{array}{l}\text { All the activities done with the purpose of improving } \\
\text { the eco-friendly performances enhance the customers' } \\
\text { abilities in order to encourage them to take } \\
\text { part in different projects. }\end{array}$ & $\begin{array}{l}\text { (Chan } \text { et al., 2012; } \\
\text { Vachon and Klassen, 2006; 2007) }\end{array}$ \\
\hline \multicolumn{4}{|c|}{ External effective factors } \\
\hline C6 & Environmental rules & $\begin{array}{l}\text { Environmental rules_even governmental or international } \\
\text { ones_which can be considered in the organization's vision } \\
\text { and influence the performance of the green supply chain. } \\
\text { Among these rules is ISO-14001 }\end{array}$ & $\begin{array}{l}\text { (Papadopouslos and Giama, 2007; } \\
\text { Kanan et al., 2014) }\end{array}$ \\
\hline $\mathrm{C} 7$ & $\begin{array}{l}\text { Coming under pressure } \\
\text { from the stakeholders }\end{array}$ & $\begin{array}{l}\text { Stakeholders of the organization can influence the } \\
\text { organization's care for the environmental factors, } \\
\text { by stressing their needs. }\end{array}$ & $\begin{array}{l}\text { (Holt and Ghobadian, 2009; } \\
\text { Govindan et al., 2013) }\end{array}$ \\
\hline \multicolumn{4}{|c|}{ s } \\
\hline $\mathrm{C} 8$ & $\begin{array}{l}\text { Environmental } \\
\text { efficiency }\end{array}$ & $\begin{array}{l}\text { This component consists of all the impacts that } \\
\text { organization activities have had on the environment, } \\
\text { in the realm of the green supply chain. These impacts can } \\
\text { be measured by operational indicators, such as energy } \\
\text { indicators, consumption and also performance } \\
\text { management such as environmental politics. }\end{array}$ & $\begin{array}{l}\text { (Liang et al., 2006; } \\
\text { Papadopouslos and Giama, 2007) }\end{array}$ \\
\hline C9 & Economic efficiency & $\begin{array}{l}\text { Financial benefits which involve the whole } \\
\text { organization and consist of annual profits, } \\
\text { market share and increased productivity. }\end{array}$ & $\begin{array}{l}\text { (Carter } \text { et al., 2000; } \\
\text { Rao and Holt, 2005) }\end{array}$ \\
\hline $\mathrm{C} 10$ & Operational efficiency & $\begin{array}{l}\text { All the advantages which are influencing the operational } \\
\text { level of the organization, such as cutting the costs, or } \\
\text { increasing the flexibility, are considered here. }\end{array}$ & $\begin{array}{l}\text { (Carter } \text { et al., 2000; } \\
\text { Rao and Holt, 2005; } \\
\text { Vachon and Klassen, 2006; 2007) }\end{array}$ \\
\hline $\mathrm{C} 11$ & $\begin{array}{l}\text { Intangible influences } \\
\text { of the performance }\end{array}$ & $\begin{array}{l}\text { Perceptional advantages such as organization's } \\
\text { social images or customer satisfaction are the intangible } \\
\text { influences that result in doing some eco-friendly } \\
\text { activities in the supply chain. }\end{array}$ & $\begin{array}{l}\text { (Smith, 2005; } \\
\text { Vachon and Klassen, 2007) }\end{array}$ \\
\hline
\end{tabular}

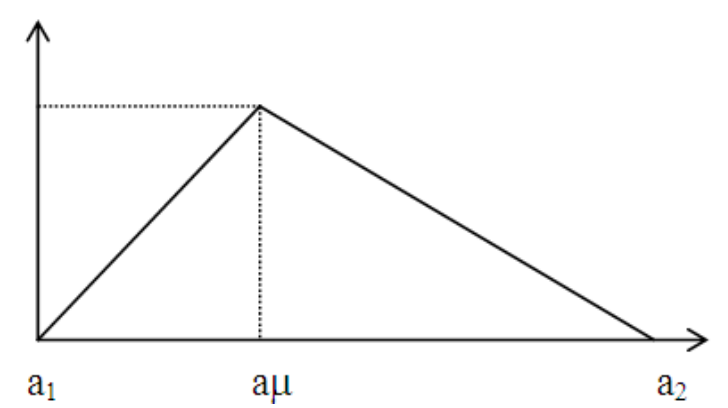

Fig. 1. The triangular fuzzy numbers
For determining the internal relationships between essential factors, experts have been asked to make pair comparisons between these factors. For the purpose of making these pair comparisons, we asked the experts to use the fuzzy numbers from Table 2.

So, the matrix " $Z$ ", called direct relationship matrix is created in the first step. One of the elements of this matrix is shown as $\left(\mathrm{a}_{1 \mathrm{ij}}^{\mathrm{k}}, \mathrm{a}_{\mu \mathrm{jij}}^{\mathrm{k}}, \mathrm{a}_{2 \mathrm{ij}}^{\mathrm{k}}\right)=\mathrm{Z}^{\mathrm{k}}$, which indicates the Kth expert's evaluation of element “ $i$ “ on the impact of element “ $\mathrm{j}$ “. In this step direct relationship matrix will be obtained. In the next step, 
matrix " $Z$ "must be normalized (Tseng and Lin, 2009) Equation (1 to 4$)$ :

$$
\begin{aligned}
& \mathrm{xa}_{1 \mathrm{ij}}^{\mathrm{k}}=\left(\mathrm{a}_{1 \mathrm{ij} \_}^{\mathrm{k}} \min _{1 \mathrm{ij}}^{\mathrm{k}}\right) / \Delta_{\min }^{\max } \\
& \mathrm{xa}_{\text {mij }}^{\mathrm{k}}=\left(\mathrm{a}^{\mathrm{k}}{ }_{\mathrm{mij}}-\min \mathrm{a}_{\mathrm{mij}}^{\mathrm{k}}\right) / \Delta_{\text {min }}^{\max } \\
& \mathrm{xa}_{2 \mathrm{ij}}^{\mathrm{k}}=\left(\mathrm{a}_{2 \mathrm{ij}-}^{\mathrm{k}}-\min \mathrm{a}_{2 \mathrm{ij}}^{\mathrm{k}}\right) / \Delta_{\text {min }}^{\max } \\
& \Delta_{\min }^{\max }=\max \mathrm{a}_{2 \mathrm{ij}-}^{\mathrm{k}} \min \mathrm{a}_{1 \mathrm{ij}}^{\mathrm{k}}
\end{aligned}
$$

In this functions;

In the 3rd step, normal left values (ls) and normal right values (rs) calculated in this way Equation (5 and 6):

$$
\begin{aligned}
& \mathrm{xls}_{\mathrm{ij}}^{\mathrm{k}}=\mathrm{xa}_{1 \mathrm{ij}}^{\mathrm{k}} /\left(1+\mathrm{xa}_{\mathrm{mij}}^{\mathrm{k}}-\mathrm{xa}_{1 \mathrm{ij}}^{\mathrm{k}}\right) \\
& \mathrm{xrs}_{\mathrm{ij}}^{\mathrm{k}}=\mathrm{xa}_{2 \mathrm{ij}}^{\mathrm{k}} /\left(1+\mathrm{xa}_{2 \mathrm{ij}}^{\mathrm{k}}-\mathrm{xa}_{\mathrm{mij}}^{\mathrm{k}}\right)
\end{aligned}
$$

Also, the final normal absolute value calculates as the following Equation (7):

$$
\mathrm{x}_{\mathrm{ij}}^{\mathrm{k}}=\left[\mathrm{xls}_{\mathrm{ij}}^{\mathrm{k}}\left(1-\mathrm{xls}_{\mathrm{ij}}^{\mathrm{k}}\right)+\mathrm{xrs}_{\mathrm{ij}}^{\mathrm{k}} * \mathrm{xrs}_{\mathrm{ij}}^{\mathrm{k}}\right] /\left(1-\mathrm{xls}_{\mathrm{ij}}^{\mathrm{k}}+\mathrm{xrs}_{\mathrm{ij}}^{\mathrm{k}}\right)
$$

The absolute value will be calculated in the next stage with the use of Equation (8):

$$
Z_{\mathrm{ij}}=\min \mathrm{a}_{\mathrm{ij}}^{\mathrm{k}}+\mathrm{x}_{\mathrm{ij}}^{\mathrm{k}} \Delta_{\min }^{\max }
$$

In the final step must join the values according to Equation (9):

$$
\mathrm{Z}_{\mathrm{ij}}=1 / \mathrm{p}\left(\mathrm{Z}_{\mathrm{ij}}^{1}+\mathrm{Z}_{\mathrm{ij}}^{2}+\ldots \mathrm{Z}_{\mathrm{ij}}^{\mathrm{p}}\right)
$$

In this research, the direct relationship matrix has become as shown in Table 3 after defuzzification of the experts' opinions.

According to the defuzzified direct relationship matrix which is a combination of experts' opinions and based on the following formulas, Normalized Direct Relationship Matrix can be created Equation (10 and 11):

$\mathrm{X}=\mathrm{s} * \mathrm{Z}$

$\mathrm{s}=1 / \max \sum_{\mathrm{J}=1}^{\mathrm{N}} \mathrm{Z}_{\mathrm{ij}} \mathrm{ij}=1,2, \ldots, \mathrm{n}$

So, the Normalized Direct Relationship Matrix in this research will be as depicted in Table 4.

In the next step, total relation matrix (T) must be calculated. Total relationship matrix in this research will be as the following, in Table 5 Equation (12):

$$
\mathrm{T}=\mathrm{X}(1-\mathrm{X})^{-1}
$$

For providing the cause and effect's graph (or table??), the total elements of the column and rows in the Total Relationship Matrix, called in turn R and D. If $\mathrm{R}+\mathrm{D}$ is big, it means that the relevant factor had many interaction (or relationships) with other factors and as a result gets a lot of importance. When D-R indicates a positive amount, we can say this factor has been the superior one. Finally, we can have the cause and effect's graph (or table??) by drawing the points with the coordinates of $(R+D, D-R)$. $R$ and $D$ related to the total matrix of the research shown in Table 6 .

Table 2. Explanatory variables and corresponding fuzzy numbers

\begin{tabular}{llll}
\hline Triangular fuzzy numbers & Explanatory scale's values & Triangular fuzzy numbers & Explanatory scale's values \\
\hline$(0,0.25,0.5)$ & Very small impact & $(1,1,0.5)$ & Huge impact \\
$(0,0,0.25)$ & With no impact & $(0.5,0.75,1)$ & Big impact \\
& & $(0.75,0.5,0.25)$ & small impact \\
\hline
\end{tabular}

Table 3. Defuzzified direct relationship matrix

\begin{tabular}{llllllllllll}
\hline & C1 & C2 & C3 & C4 & C5 & C6 & C7 & C8 & C9 & C10 & C11 \\
\hline C1 & 0.000 & 0.966 & 0.697 & 0.697 & 0.697 & 0.000 & 0.445 & 0.966 & 0.697 & 0.697 & 0.966 \\
C2 & 0.697 & 0.000 & 0.697 & 0.966 & 0.966 & 0.697 & 0.445 & 0.966 & 0.966 & 0.966 & 0.966 \\
C3 & 0.000 & 0.211 & 0.000 & 0.697 & 0.697 & 0.211 & 0.445 & 0.966 & 0.966 & 0.966 & 0.697 \\
C4 & 0.211 & 0.445 & 0.445 & 0.000 & 0.000 & 0.211 & 0.445 & 0.697 & 0.966 & 0.697 & 0.966 \\
C5 & 0.697 & 0.697 & 0.445 & 0.445 & 0.000 & 0.000 & 0.445 & 0.697 & 0.697 & 0.697 & 0.697 \\
C6 & 0.966 & 0.966 & 0.697 & 0.966 & 0.966 & 0.000 & 0.697 & 0.697 & 0.966 & 0.966 & 0.697 \\
C7 & 0.445 & 0.445 & 0.211 & 0.697 & 0.697 & 0.000 & 0.000 & 0.697 & 0.445 & 0.445 & 0.445 \\
C8 & 0.445 & 0.697 & 0.697 & 0.445 & 0.211 & 0.445 & 0.445 & 0.000 & 0.445 & 0.697 & 0.697 \\
C9 & 0.697 & 0.697 & 0.697 & 0.697 & 0.697 & 0.000 & 0.445 & 0.697 & 0.000 & 0.966 & 0.697 \\
C10 & 0.697 & 0.697 & 0.697 & 0.697 & 0.697 & 0.000 & 0.445 & 0.697 & 0.697 & 0.000 & 0.697 \\
C11 & 0.445 & 0.445 & 0.697 & 0.697 & 0.697 & 0.000 & 0.697 & 0.697 & 0.697 & 0.697 & 0.000 \\
\hline
\end{tabular}


Table 4. Normalized direct relationship matrix

\begin{tabular}{llllllllllll}
\hline & C1 & C2 & C3 & C4 & C5 & C6 & C7 & C8 & C9 & C10 & C11 \\
\hline C1 & 0.000 & 0.112 & 0.081 & 0.081 & 0.081 & 0 & 0.051 & 0.112 & 0.081 & 0.081 & 0.112 \\
C2 & 0.081 & 0.000 & 0.081 & 0.112 & 0.112 & 0.08 & 0.051 & 0.112 & 0.112 & 0.112 & 0.112 \\
C3 & 0.000 & 0.024 & 0.000 & 0.081 & 0.081 & 0.02 & 0.051 & 0.112 & 0.112 & 0.112 & 0.081 \\
C4 & 0.024 & 0.051 & 0.051 & 0.000 & 0.000 & 0.02 & 0.051 & 0.081 & 0.112 & 0.081 & 0.112 \\
C5 & 0.081 & 0.081 & 0.051 & 0.051 & 0.000 & 0.000 & 0.051 & 0.081 & 0.081 & 0.081 & 0.081 \\
C6 & 0.112 & 0.112 & 0.081 & 0.112 & 0.112 & 0.000 & 0.081 & 0.081 & 0.112 & 0.112 & 0.081 \\
C7 & 0.051 & 0.051 & 0.024 & 0.081 & 0.081 & 0.000 & 0.000 & 0.081 & 0.051 & 0.051 & 0.051 \\
C8 & 0.051 & 0.081 & 0.081 & 0.051 & 0.024 & 0.050 & 0.051 & 0.000 & 0.051 & 0.081 & 0.081 \\
C9 & 0.081 & 0.081 & 0.081 & 0.081 & 0.081 & 0.000 & 0.051 & 0.081 & 0.000 & 0.112 & 0.081 \\
C10 & 0.081 & 0.081 & 0.081 & 0.081 & 0.081 & 0.000 & 0.051 & 0.081 & 0.081 & 0.000 & 0.081 \\
C11 & 0.051 & 0.051 & 0.0812 & 0.0812 & 0.081 & 0.000 & 0.081 & 0.081 & 0.081 & 0.081 & 0.000 \\
\hline
\end{tabular}

Table 5. The total relationship matrix

\begin{tabular}{llllllllllll}
\multicolumn{1}{l}{ Table 5. } & C1 & C2 & C3 & C4 & C5 & C6 & C7 & C8 & C9 & C10 & C11 \\
\hline C1 & 0.144 & 0.273 & 0.249 & 0.267 & 0.245 & 0.051 & 0.1890 & 0.3210 & 0.2830 & 0.2920 & 0.3160 \\
C2 & 0.255 & 0.212 & 0.287 & 0.337 & 0.310 & 0.132 & 0.2210 & 0.3670 & 0.3570 & 0.3680 & 0.3620 \\
C3 & 0.126 & 0.169 & 0.145 & 0.235 & 0.216 & 0.062 & 0.1670 & 0.2830 & 0.2760 & 0.2850 & 0.2520 \\
C4 & 0.135 & 0.178 & 0.181 & 0.146 & 0.133 & 0.059 & 0.1560 & 0.2390 & 0.2590 & 0.2400 & 0.2620 \\
C5 & 0.195 & 0.217 & 0.192 & 0.207 & 0.141 & 0.040 & 0.1640 & 0.2550 & 0.2450 & 0.2530 & 0.2510 \\
C6 & 0.290 & 0.323 & 0.294 & 0.347 & 0.321 & 0.060 & 0.2520 & 0.3510 & 0.3670 & 0.3770 & 0.3460 \\
C7 & 0.146 & 0.164 & 0.139 & 0.201 & 0.186 & 0.033 & 0.0920 & 0.2190 & 0.1860 & 0.1920 & 0.1920 \\
C8 & 0.165 & 0.212 & 0.214 & 0.205 & 0.164 & 0.088 & 0.1620 & 0.1750 & 0.2170 & 0.2490 & 0.2450 \\
C9 & 0.208 & 0.233 & 0.235 & 0.251 & 0.232 & 0.045 & 0.1770 & 0.2770 & 0.1920 & 0.3020 & 0.2720 \\
C10 & 0.202 & 0.226 & 0.228 & 0.244 & 0.225 & 0.044 & 0.1720 & 0.2690 & 0.2590 & 0.1920 & 0.2650 \\
C11 & 0.168 & 0.191 & 0.217 & 0.233 & 0.215 & 0.040 & 0.1914 & 0.2566 & 0.2475 & 0.2548 & 0.1767 \\
\hline
\end{tabular}

Table 6. Components and their value of R and D

\begin{tabular}{llllrr}
\hline Code & component & $\mathrm{D}$ & $\mathrm{R}$ & $\mathrm{D}-\mathrm{R}$ & $\mathrm{D}+\mathrm{R}$ \\
\hline C1 & Green purchase & 2.6358 & 2.03700 & 0.5988 & 4.6720 \\
C2 & Green designing & 3.2131 & 2.40300 & 0.8094 & 5.6160 \\
C3 & Reverse Logistics & 2.2225 & 2.38570 & -0.1632 & 4.6080 \\
C4 & Close cooperation with customers & 1.9924 & 2.67700 & -0.6849 & 4.6690 \\
C5 & Close cooperation with suppliers & 2.1629 & 2.39200 & -0.2295 & 4.5550 \\
C6 & Environmental rules & 3.3330 & 0.65880 & 2.6742 & 3.9918 \\
C7 & Coming under pressure from the stakeholders & 1.7543 & 1.94900 & -0.1951 & 3.7037 \\
C8 & Environmental efficiency & 2.1009 & 3.01600 & -0.9155 & 5.1173 \\
C9 & Economic efficiency & 2.4282 & 2.89300 & -0.4656 & 5.3220 \\
C10 & Operational efficiency & 2.3318 & 3.00900 & -0.6772 & 5.3408 \\
C11 & Intangible influences of the performance & 2.1933 & 2.94400 & -0.7514 & 5.1380 \\
\hline
\end{tabular}

One of the functions of the DEMATEL method is giving the structure to the complicated factors in the format of cause and effect groups. So, DEMATEL can divide the enormous sets of factors into the cause and effect groups and help the decision-maker to understand the conditions much better. $(\mathrm{D}+\mathrm{R})$ is the horizontal axis of the graph which is called importance axis. (D-R) is the vertical axis of the graph which is called relationship axis. With applying this procedure, the cause and effect graph that is comprised of sub-components, will be as Fig. 2.

We can follow the same procedure for three major components of this research and draw its cause and effect graph in Fig. 3.

\subsection{The Research Achievements}

This study pays attention to the executing of green supply management, in order to improve it. eleven major sub- components which are considered in previous studies have been applied. As a result of asking the experts' advices in Saipa Group, the components divided into two cause and effect groups in order to identify the mutual relationships of the components. The cause and effect graph in Fig. 2 can display the sub-components' positions according to the factors; importance and relationships. Therefore, some sub- components such as, green purchase (C1), green designing (C2) and environmental rules (C6) are the ones that can affect on the system. 


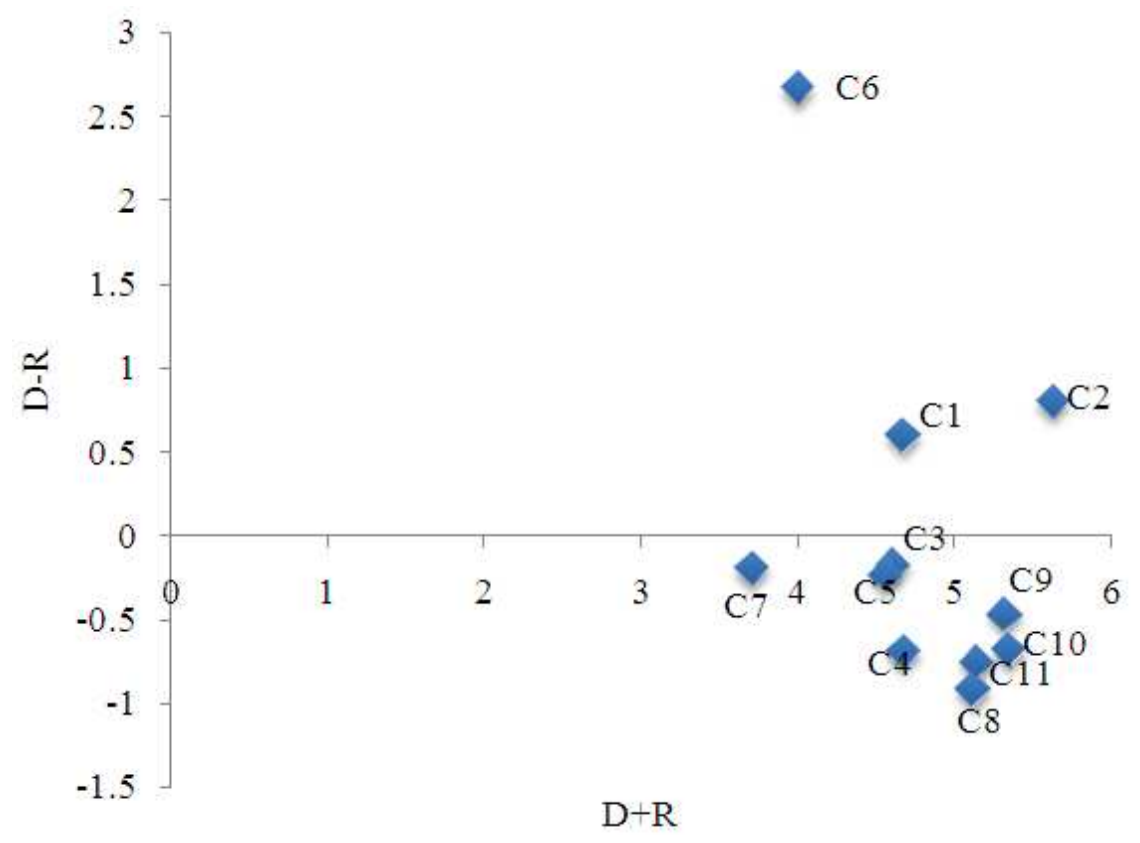

Fig. 2. The cause and effect graph of sub-components

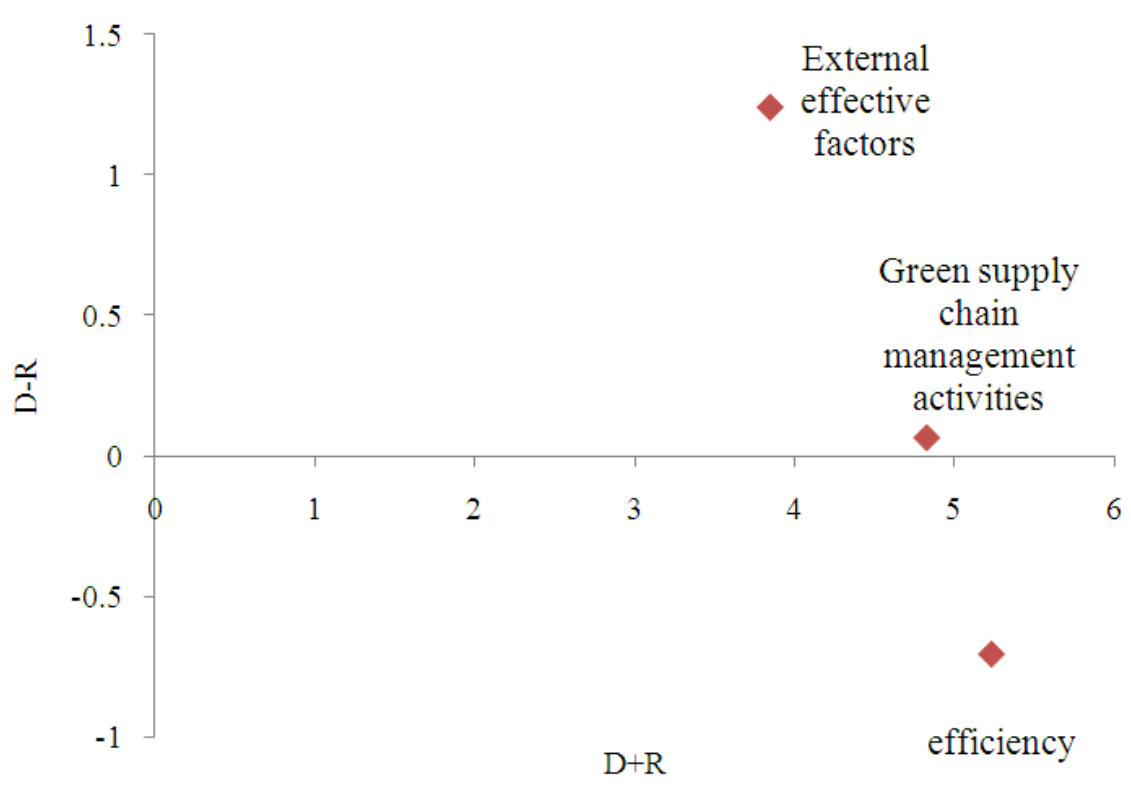

Fig. 3. The cause and effect graph of major components

But, other components such as, reverse logistic (C3), close cooperation with customers (C4), close cooperation with suppliers (C5), coming under pressure from the stakeholders (C7), Environmental efficiency (C8), Economic efficiency (C9), operational efficiency (C10) and intangible influences of the performance (C11) are the sub-components that take effect of the system rather than affect on it.

Since the cause sub- components have an effect on the whole system, their performance can highly affect 
the main goal. So, we have to pay attention more deeply to them. If you take a look at (D-R) column, you can realize that among the cause sub-components, environmental rules with the score of 2.607 have a huge impact on the system. This score has a significant difference with others and as a result, can play a very important role in succeeding the green supply chain management. In Table 6, the column D represents the amount of impacts that a sub-component has on the others. The column $\mathrm{R}$ represents the amount of impacts that a sub-component receive from the others. As you see, environmental rules have the highest score among the other sub-components, although it receives the less impact from them.

The following sub-components, located in the positive zone of the axis, are the sub-components of green purchase and green designing. Green designing has the second rank and after environmental rules, it has the highest score in column D. So, this sub- component is very important and has a great impact on the other sub- components. Actually, the green designing has been located in the far distance of the coordinate axis. It was said that the horizontal axis shows the (D+R) which is called, importance axis. According to the expert's opinion, green designing is not only the most important sub-component among the others, but also in the whole system. As a result, the management has to consider the way of designing the product in order not to harm the environment in each step of life cycle. Green purchase is one of the cause sub-components, as well. So the way of implementing this sub-component can influence the main purpose of supply chain, i.e. safeguarding the environment. Therefore, the products could be made of materials which are not harmful to the environment and have could be recycled.

The rest of the sub-components of the system are located in the negative zone of the graph. In other words, all of them are the effect components. Among them, reverse logistic has the shortest distance from the positive zone of the axis. So, it receives the less impact from the other sub- components. Environmental efficiency receives the most impact from the others. This is completely logical, because while you consider the environmental issues in purchasing green material or designing the product, the organization's activity will have positive impact on the environment and boost the organization performance. Operational efficiency, after green designing, has the highest amount of (D+R). So, it can be very important for the organization. Actually, according to the achievements of the research, some issues such as productivity, efficiency, economic efficiency and intangible influences of the performance are really crucial for the managers in the green supply chain and thus, the organization is eager to obey the environmental rules with the intention of getting notable economic achievements. By the way, obeying the environmental rules will earn a good reputation for the organization and it can make some better intangible influences.

Also, the cause and effect graph of components, i.e., the Table 2, shows, between three major components, green supply chain management activities and external effective factors can affect the whole system. Organizational efficiency is the only component which is affected by the system. External effective factors have most impact on the whole system, while the green supply chain management activities, because of having the longest distance from the coordinate axes. It is very important for the organization and handle it properly can improve the organization's efficiency.

\section{CONCLUSION}

This research has taken into consideration the study of effective components in executing the green supply chain, in order to give a better understanding of deserving the environmental. The DEMATEL method has been used with the intention of determining the mutual relationships between the effective factors in the green supply chain. Since the fuzzy sets theory can remove any ambiguity relevant to the explanatory figures, it has been applied for developing the group DEMATEL method.

The fuzzy group DEMATEL method can divide the components into two cause and effect groups. The conclusion of applying this method confirms that environmental rules, green designing and green purchase are three sub- components which are considered as cause group. Among other things, environmental rules have the most effect on the system. The rests are among the effect components and environmental efficiency take the most effect from other sub_components. This piece of information will be of use to the business managers, in order to realize that for handling the green supply chain have to consider which one of these sub- components more significantly and which one is not that much important to be considered. Actually, this study represented that among the three major components; i.e., green supply chain management activities, external effective factors and organizational efficiency, only green supply chain management activities and external effective factors influence the system and the 
organizational efficiency is affected by the system. This categorization can help the decision maker to take a better understanding of the conditions and to create a much more efficient supply chain.

\subsection{Limitations}

This study faces some restrictions. We should mention that the findings of this research have not been applied in action in the real world. So, it is recommended to do scientific researches in a particular industry, in the near future.

\subsection{Future Study}

Components that are studied in this research can improve our knowledge about management of green supply chain. But advancement in this area should be considered continually. So it is absolutely essential to study this matter from knowledge management perspective in future studies. Implementation of appropriate systems to manage knowledge can increase the chances of successful supply chain.

Besides, new technologies of production have been established nowadays. Development of different models in order to investigate impact of these technologies such as RFID on green supply chain performance can be helpful.

It is obvious that suppliers play important role in the success of green supply chain. That is why designing a comprehensive model for supplier selection with environmental approaches or the way of obtaining coordination among supplier and manufacturers seem remarkable.

\section{REFERENCES}

Alvarez-Gil, M.J., P. Berrone, F.J. Husillos and N. Lado, 2007. Reverse logistics, stakeholders' influence, organizational slack and managers' posture. J. Bus. Res., 60: 463-473. DOI: 10.1016/j.jbusres.2006.12.004

Carter, C.R., R. Kale and C.M. Grimm, 2000. Environmental purchasing and firm performance: An empirical investigation. Trans. Res. Part E, 36: 219-228. DOI: 10.1016/S1366-5545(99)00034-4

Chan, R.Y.K., H. He, H.K. Chan and W.Y.C. Wang, 2012. Environmental orientation and corporate performance: The mediation mechanism of green supply chain management and moderating effect of competitive intensity. Indus. Market. Manage., 41: 621-630. DOI: 10.1016/j.indmarman.2012.04.009
Cheng, J.H., 2011. Inter-organizational relationships and knowledge sharing in green supply chainsmoderating by relational benefits and guanxi. Trans. Res., 47: 837-849. DOI: 10.1016/j.tre.2010.12.008

Chung, C.J. and H.M. Wee, 2011. Short life-cycle deteriorating product remanufacturing in a green supply chain inventory control system. Int. J. Product. Econ., 129: 195-203. DOI: 10.1016/j.ijpe.2010.09.033

Diabat, A. and K. Govindan, 2011. An analysis of the drivers affecting the implementation of green supply chain management. Resou. Conserv. Recycl., 55: 659-667. DOI: 10.1016/j.resconrec.2010.12.002

EC, 2000. Directive 2000/53/EC of the European parliament and of the council of 18 September 2000 on end-of-life vehicles. Official J. Eur. Commun., L269: 34-42.

Eltayeb, T.K., S. Zailani and T. Ramayah, 2011. Green supply chain initiatives among certified companies in Malaysia and environmental sustainability: Investigating the outcomes. Resou. Conserv. Recycl., 55: 495-506. DOI: 10.1016/j.resconrec.2010.09.003

Farzianpour, F., J. Khaniki, F. Batebi and M. Younesian, 2012. Compare the effects of two educational methods on the health principles knowledge of employees in food preparation. Am. J. Applied Sci., 9: 1678-1683. DOI: 10.3844/ajassp.2012.1678.1683

Farzianpour, F., J. Khaniki, M. Younesian, M. Sadeghi and S.H. Hosseini, 2013a. Evaluation of food color consumption and determining color type by thin layer chromatography. Am. J. Applied Sci., 10: 172-178. DOI: 10.3844/ajassp.2013.172.178

Farzianpour, F., M. Pishdar, M.D. Shakib, S. Hashemi and M.R. Toloun, 2014. Consumers' perceived risk and its effect on adoption of online banking services. Am. J. Applied Sci., 11: 47-56. DOI: 10.3844/ajassp.2014.47.56

Farzianpour, F., S. Hosseini, A. Mirsepasi, H. Honary and S.S. Hosseini, 2013b. Internal evaluation of the department of environmental health science and engineering. Am. J. Applied Sci., 10: 58-63. DOI: 10.3844/ajassp.2013.58.63

Govindan, K., S. Rajendran, J. Sarkis and P. Murugesan, 2013. Multi criteria decision making approaches for green supplier evaluation and selection: A literature review. J. Cleaner Product. DOI: 10.1016/j.jclepro.2013.06.046 
Hervani, A.A., M.M. Helms and J. Sarkis, 2005. Performance measurement for green supply chain management. Benchmark. Int. J., 12: 330-353. DOI: 10.1108/14635770510609015

Holt, D. and A. Ghobadian, 2009. An empirical study of green supply chain management practices amongst UK manufacturers. J. Manufact. Technol. Manage., 20: 933-956. DOI: 10.1108/17410380910984212

Igarashi, M., L. De Boer and A.M. Fet, 2013. What is required for greener supplier selection? A literature review and conceptual model development. J. Purchas. Supply Manage., 19: 247-263. DOI: 10.1016/j.pursup.2013.06.001

Kanan, D., A.B. Jabbour and C.J. Chiappetta Jabbour, 2014. Selecting green suppliers based on GSCM practices: Using fuzzy TOPSIS applied to a Brazilian electronics company. Eur. J. Operat. Res., 233: 432-447. DOI: 10.1016/j.ejor.2013.07.023

Li, Y., Y. Liu and H. Liu, 2011. Co-opetition, distributor's entrepreneurial orientation and manufacturer's knowledge acquisition: Evidence from China. J. Operat. Manage., 29: 128-142. DOI: 10.1016/j.jom.2010.07.006

Liang, L., F. Feng, W.D. Cook and J.D.E. Zhu, 2006. DEA models for supply chain efficiency evaluation. Annals Operat. Res., 145: 35-49. DOI: 10.1007/s10479-006-0026-7

Lin, R.J., 2011. Using fuzzy DEMATEL to evaluate the green supply chain management practices. J. Cleaner Product., 40: 32-39. DOI: 10.1016/j.jclepro.2011.06.010

Lin, R.J., 2013. Using fuzzy DEMATEL to evaluate the green supply chain management practices. J. Cleaner Product., 40: 32-39. DOI: 10.1016/j.jclepro.2011.06.010

Olugu, E.U., K.Y. Wong and A.M. Shaharoun, 2011. Development of key performance measures for the automobile green supply chain. Resou. Conserv. Recycl., 55: 567-579. DOI: 10.1016/j.resconrec.2010.06.003

Papadopouslos, A.M. and E. Giama, 2007. Environmental performance evaluation of thermal insulation materials and its impact on the building. Build. Environ. 2: 2178-2187. DOI: 10.1016/j.buildenv.2006.04.012

Rao, P. and D. Holt, 2005. Do green supply chains lead to competiveness and economic performance. Internal J. Operat. Product. Manage., 25: 898-898. DOI: $10.1108 / 01443570510613956$
Richey, R.G., M. Tokman, R.E. Wright and M.G. Harvey, 2005. Monitoring reverse logistics programs: A roadmap to sustainable development in emerging markets. Multinat. Bus. Rev., 13: 4165. DOI: $10.1108 / 1525383 X 200500014$

Setthasakko, W., 2009. Barriers to implementing corporate environmental responsibility in Thailand-a qualitative approach. Int. J. Org. Anal., 17: 169-183. DOI: 10.1108/19348830910974905

Smith, A.D., 2005. Reverse logistics programs: Gauging their effects on CRM and online behavior. VINE, 35: 166-181. DOI: 10.1108/03055720510634216

Tseng, M.L. and Y.H. Lin, 2009. Application of fuzzy DEMATEL to develop a cause and effect model of municipal solid waste management in Metro Manila. Environ. Monit. Assess., 158: 519-533. DOI: 10.1007/s10661-008-0601-2

Tseng, M.L., 2010. Using linguistic preferences and grey relational analysis to evaluate the environmental knowledge management capacity. Expert Syst. Appli., 37: 70-78. DOI: 10.1016/j.eswa.2009.05.020

Tseng, M.L., 2011a. Using a hybrid MCDM model to evaluate firm environmental knowledge management in uncertainty. Applied Soft Comput., 11: 1340-1352. DOI: 10.1016/j.asoc.2010.04.006

Tseng, M.L., 2011b. Green supply chain management with linguistic preferences and incomplete information. Applied Soft Comput., 11: 4894-4903. DOI: 10.1016/j.asoc.2011.06.010

Tseng, M.L., W.W. Wu, Y.H. Lin and C.H. Liao, 2008. An exploration of relationships between environmental practice and manufacturing performance using the PLS path modeling. WSEAS Trans. Environ. Dev., 4: 487-502.

Tzeng, G. and S. Opricovic, 2003. Defuzzification within a multicriteria decision model. Int. J. Uncert. Fuzziness Knowl. Based Syst., 11: 635-652. DOI: 10.1142/S0218488503002387

US-AEP, 1999. Sector based public policy in the AsiaPacific Region. US-AEP.

Vachon, S. and R.D. Klassen, 2006. Extending green practices across the supply chain: The impact of upstream and downstream integration. Int. J. Operat. Product. Manage., 26: 795-821. DOI: 10.1108/01443570610672248

Vachon, S. and R.D. Klassen, 2007. Supply chain management and environmental technologies: The role of integration. Int. J. Product. Res., 45: 410-423. DOI: $10.1080 / 00207540600597781$ 
Wallace, D.P., C.V. Fleet and L.J. Downs, 2011. The research core of the knowledge management literature. Int. J. Inform. Manage., 31: 14-20. DOI: 10.1016/j.ijinfomgt.2010.10.002

Wang, X.Y. and J.H. Zhang, 2010. Research on management complexity in supply chain problems based on DEMATEL.

Wheeler, M., A. Sharp, M. Nenycz-Thiel, 2013. The effect of 'green' messages on brand purchase and brand rejection. Australasian Market. J., 21: 105-110. DOI: 10.1016/j.ausmj.2013.02.007

Zadeh, L., 1965. Fuzzy sets. Inform. Control, 8: 338-353. DOI: 10.1016/S0019-9958(65)90241-X
Zhu, Q., J. Sarkis and K. Lai, 2007. Green supply chain management: Pressures, practices and performance within the Chinese automobile industry. J. Cleaner Product., 15: 1041-1052. DOI: 10.1016/j.jclepro.2006.05.021

Zhu, Q., Y. Geng, J. Sarkis and K.H. Lai, 2011. Evaluating green supply chain management among Chinese manufacturers from the ecological modernization perspective. Trans. Res. Part E: Logistics Trans. Rev., 47: 808-821. DOI: 10.1016/j.tre.2010.09.013 